\title{
Mammary microbiota of dairy ruminants: fact or fiction?
}

\author{
Pascal Rainard* ${ }^{*}$
}

\begin{abstract}
Explorations of how the complex microbial communities that inhabit different body sites might contribute to health and disease have prompted research on the ways the harmonious relationship between a host and its microbiota could be used to keep animals healthy in their production conditions. In particular, there is a growing interest in the bacterial signatures that can be found in the milk of healthy or mastitic dairy cows. The concept of sterility of the healthy mammary gland of dairy ruminants has been challenged by the results of studies using bacterial DNAbased methodology. The newly obtained data have led to the concept of the intramammary microbiota composed of a complex community of diverse bacteria. Accordingly, mammary gland infections are not mere infections by a bacterial pathogen, but the consequence of mammary dysbiosis. This article develops the logical implications of this paradigm shift and shows how this concept is incompatible with current knowledge concerning the innate and adaptive immune system of the mammary gland of dairy ruminants. It also highlights how the concept of mammary microbiota clashes with results of experimental infections induced under controlled conditions or large field experiments that demonstrated the efficacy of the current mastitis control measures.
\end{abstract}

\section{Table of contents}

1 The notion of mammary microbiota challenges the concept of mammary gland sterility

2 The milk sampling issue: the contamination controversy

3 Mammary microbiota and the innate immunity of the MG

3.1 Milk is a nutrient-rich medium that supports the growth of bacteria

3.2 The mammary gland is poised to sense and to react to MAMPs

3.3 There is no mucus shield to protect the mammary epithelium from a microbiota

3.4 Absence or rarity of isolated lymphoid follicles

3.5 Inefficiency of the entero-mammary pathway in ruminants

4 Mammary microbiota compatibility with the five-point mastitis control plan

*Correspondence: pascal.rainard@inra.fr

ISP, INRA, Université de Tours, UMR1282, 37380 Nouzilly, France
5 An implication of mammary microbiota: use of probiotics for the mammary gland

6 The concept of mammary microbiota needs thorough examination

\section{The notion of mammary microbiota challenges the concept of mammary gland sterility}

There is currently a lively interest among biologists in the interactions between hosts and the microbiota associated with mucosal or cutaneous epithelia. The human body hosts complex microbial communities whose composition is determined primarily by body habitat [1]. It is now widely accepted that the harmonious relationship between the host and its microbiota contributes to health. In particular, the microbiota plays a fundamental role in the induction, training, and function of the host's immune system [2]. Most studies have dealt with the skin or gut microbiota, but other body sites are now considered as harbouring their own microbiota, such as the oro-pharyngeal, urinary and genital tracts and even 
the lung [3]. Recently, the mammary gland (MG) has also been included among these sites.

The widely held belief that the lumen of the healthy MG is sterile has been challenged recently. Although the MG has been considered a sterile organ, application of molecular methods to the quantification and sequencing of bacterial DNA has yielded results suggesting that there are commensal microbial communities within the MG $[4,5]$. These results challenge the notion that the healthy MG is sterile, and they have led to a paradigm shift prompting some researchers to consider mastitis, which used to be considered a host-pathogen interaction driven by host and bacterial determinants, as a manifestation of dysbiosis, i.e. an imbalance of the mammary microbiota [4-6]. This novel concept is the rationale behind research programs aimed at defining the intramammary microbiota and is arousing interest in the impact of commensal microorganisms on the immune response to mastitiscausing bacteria, or intentional intramammary instillation of probiotics to cure or prevent mastitis.

There are many significant implications of the existence of an intramammary microbiota. However, they have not been clearly stated, analysed in depth, or discussed. The aim of this paper is to develop the implications of a mammary microbiota and to consider this paradigm shift in relation to the current views of the pathogenesis of infectious mastitis and of MG immunobiology, and to the current mastitis control measures.

It has long been considered that the MG is naturally free of resident bacteria and that the milk of a healthy MG is germ-free. The theory that milk within the healthy udder is germ-free was advanced in the years 1874-1878 [7]. Soon after, the theory that the udder is inhabited by a "normal flora" consisting of bacteria always found in the environment of cattle was put forward, as reported by Plastridge [8]. This theory was abandoned following studies showing that milk from healthy glands was normally sterile, on the basis of conventional bacterial culturing applied to aseptically taken milk samples. The researchers who were advocates of MG sterility stressed that precautions for aseptic milk sampling were of the utmost importance to get reliable results, stressing that obtaining sterile milk samples in the cowshed or milking parlour is impractical, and that the most reliable method of determining whether the bacteria have an intramammary source is by teat wall puncture [9].

Recently, with the advent of culture-independent methods of microbial identification, the concept of a sterile intramammary milieu has been challenged anew and more and more studies report that the healthy MG accommodates rather large and varied bacterial populations. Not all researchers and practitioners were satisfied with the bacteriological procedures in use previously.
They have stressed the shortcomings of the classical bacteriological analysis, in particular the high rate of nogrowth samples, i.e. milk samples taken from an inflamed MG that did not yield cultivable bacteria [10]. It was suspected that routine techniques were not adapted to the growth of many mammary pathogens, and alternative methods were proposed. In particular, detection methods based on the amplification of bacterial DNA were used. These new techniques provided results that contradicted the cultural methods: bacteria of many genera were found in milk from healthy MG $[4,11]$. These results were interpreted as resulting from the existence of a mammary microbiota that would inhabit every MG, healthy or not [12]. This new concept had been developed in the last decade by some groups of researchers working on mastitis in breast-feeding women $[5,13]$.

The breast milk microbiota concept called into question the accepted view of breast sterility. This view had been stated in a World Health Organisation report [14]. In this report, it was considered that it is common knowledge that bacteria are often found in milk from asymptomatic breasts, with a bacterial spectrum very similar to that found on skin, including staphylococci and streptococci. It is noteworthy that despite careful techniques for collection, only $50 \%$ of milk cultures may be sterile, while others show "normal" colony counts ranging from 0 to 2500 colonies $/ \mathrm{mL}$. These bacteria may be skin contaminants or bacteria shed from colonized milk ducts. It was accepted that aseptically taken milk samples could be loaded with a few bacteria $\left(<10^{3} / \mathrm{mL}\right.$ milk) during their passage through the nipple ducts [15]. Bacterial colonization of the infant and breast is a normal process that takes place soon after birth. Both the mother's milk ducts and the infant's nasopharynx are colonized by a variety of organisms, some of them potentially pathogenic, such as Staphylococcus aureus [16].

This view was regarded as outdated by some researchers, and a new school of thought has emerged in the last decade, based on the increasing use of "omics" approaches. Although aseptic collection of human milk is questioned, culture-dependent methods have found bacteria in milk assumed to be aseptically collected. This has led to the notion of the human milk microbiota: it is considered normal that human milk from healthy women contains $10^{3}-10^{4} \mathrm{cfu}$ of diverse bacteria per $\mathrm{mL}$ [13]. The most commonly isolated bacterial species from human milk include Staphylococcus epidermidis, S. aureus, Streptococcus mitis, Streptococcus salivarius, Lactobacillus salivarius, Lactobacillus fermentum, Lactobacillus gasseri, Lactobacillus rhamnosus, Bifidobacterium breve and Bifidobacterium bifidum [13]. It is noteworthy that many of these species are members of the normal flora of the skin and the oro-pharynx. The number of cultivable 
bacterial species that can be found within one individual ranges from 2 to 18 different species, but this number has been substantially increased by the use of culture-independent techniques, based on the amplification of the variable regions in genes coding for $16 \mathrm{~S}$ ribosomal RNA (16S rDNA), associated or not with pyrosequencing of the gene $[5,17]$. From the data establishing the existence of a milk sample microbiome, some authors assumed the existence of a commensal microflora of human milk and of a mammary microbiota [13].

The mechanism by which bacteria reach the mammary gland has been the subject of debate and speculation. The proposed view is that bacteria from the gut microbiota would reach the mammary gland by an endogenous route [18]. It is speculated that bacteria taken up from the gut lumen by leucocytes such as dendritic cells or macrophages would be carried to the mammary gland by phagocytes migrating to the mammary gland by the haematogenous route, then making their way to the mammary gland lumen to be finally shed in milk. It has been shown that translocation of bacteria from the gut lumen to milk in mononuclear leucocytes may occur in lactating mice for a short period after delivery [15]. This entero-mammary pathway has been described for lymphocytes primed in the gut or the associated lymph nodes. These cells would then migrate to other mucosal sites, including the mammary gland [19]. This possibility is discussed below.

The concept of human mammary gland microbiota was proposed to be applied to the bovine mammary gland [20], and this idea was taken up in later studies. By using metagenomics pyrosequencing of bacterial 16S rRNA genes, a wide variety of bacterial species were found in each of the milk samples of mastitic and healthy cows [4]. It was also found that the microbiota of milk specimens derived from healthy cows was different from the microbiota of the mastitic specimens. This finding and the fact that members of several bacterial genera were found in every sample obtained from healthy quarters led the authors to postulate the existence of a microbiota indigenous to the bovine mammary gland [12]. It is noteworthy that S. aureus and Streptococcus uberis DNA were found in milk samples from healthy quarters with low somatic cell counts, leading the authors to postulate that these bacterial species that are known to exist on the skin or in the intestinal tract of the cow are part of the normal microbiota of the mammary gland. As in cases of clinical mastitis caused by one of these pathogens, these bacteria dominated the milk sample microflora [4], the conclusion was drawn that these infections were the result of dysbiosis of the mammary gland microbiota (or dysbacteriosis) rather than a mere primary infection [12]. In another study, an average of 30 different bacterial genera were found in samples from mastitic or healthy bovine mammary quarters [11]. It is noteworthy that the amount of DNA in samples from healthy quarters was so low that a DNA amplification step was necessary before polymerase chain reaction (PCR) amplification and $16 \mathrm{~S}$ rRNA gene analysis. It is important to bear in mind that these two amplification steps make the procedure exquisitely sensitive, and prone to detecting the slightest contamination of the sample, which would be difficult to avoid even in a surgical ward. Intriguingly, this study showed significant differences in the bacterial populations in milk samples from quarters showing signs of clinical mastitis in comparison to milk samples from healthy quarters.

\section{The milk sampling issue: the contamination controversy}

By using usual culture-dependent techniques and nonselective culture media, bovine milk samples taken from healthy uninflamed glands with thorough aseptic precautions yield only very low numbers of colonies, so that $50 \mu \mathrm{L}$ samples are usually devoid of cultivable bacteria $(<20 \mathrm{cfu} / \mathrm{mL})$. Under field conditions, it is easy to contaminate milk samples: "milk drawn by hand from a healthy gland through the teat duct will nearly always contain bacterial contaminants from the teat duct, teat lesions, udder skin or the hands of the sampler" [9]. As a consequence, the volume of milk used to seed plates of non-selective medium, usually aesculin blood agar, is restricted to $50 \mu \mathrm{L}$, and more often $10 \mu \mathrm{L}$. More than 137 species of microorganisms are able to cause bovine mastitis [21], but every mastitis case is generally considered to be caused by one primary pathogen, because usually only one bacterial species is identified in milk samples from diseased glands [22]. Nevertheless, simultaneous infections by two different pathogen species are not rare, and three pathogens may be found in a small proportion of cases. Generally, samples yielding three or more than three bacterial species are suspected to be contaminated. Indeed, caution should be exercised in the interpretation of bacteriological analysis results. Hand collection of milk almost inevitably contaminates the sample with bacteria that colonize the distal part of the teat canal and the skin of the teat apex, or that simply soil the teat apex. A rich diversity of bacterial species can be found on teat apices [23]. Even extreme care used to disinfect the teat apex is not a foolproof guarantee that the sample will not be contaminated, in particular under field conditions. A procedure less prone to contamination is the use of a disposable collection bag fitted with a blunt cannula [24]. After careful disinfection of the teat apex, the cannula is introduced through the teat canal and the milk is aspirated. Another advantage of this technique is that it enables the cultivation 
of anaerobic bacteria. By using this approach, it was found that milk from healthy quarters yielded negative cultures; that most samples from classical clinical mastitis yielded only one bacterial species; and that samples from quarters with summer mastitis-like signs yielded an average of 3.4 bacterial species [25]. Another way of getting cistern milk by bypassing the teat canal is the trans-parietal route, using a syringe and needle. A great number of precautions must also be taken under field conditions, such as shaving and thorough disinfection of the udder skin to avoid contaminating the samples. This has been shown for blood culture tests: if these precautions are not taken, it is difficult to get uncontaminated blood samples [25].

The issue of milk sample contamination is compounded by the volume of milk sample necessary to perform the analyses: for bacteriological cultivation, the standard volume is reduced to $10 \mu \mathrm{L}$. It is noteworthy that pyrosequencing uses approximately 100 times ( $1 \mathrm{~mL}$ milk) and qPCR 35 times the amount of milk compared to classical culture, and these techniques detect both dead and live microorganisms [4]. Consequently, very careful collection of milk samples is even more important for DNA-based methods than for conventional culture methods [26]. As noted above, many of the bacteria found by the DNA-based techniques are common inhabitants of the skin, the gut, or the mouth (breast milk samples). Also, many of the bacteria composing the milk microbiota of healthy MGs have the potential for causing mastitis. This is particularly the case with bacteria of the genera Staphylococcus, Streptococcus, Pseudomonas, Corynebacterium, and Burkholderia $[4,11]$. Absence of inflammation in these MG is thus unexpected. Bacterial communities commonly found in raw cow milk comprise bacterial genera that were also found in studies on the milk microbiota, such as Sphingomonas and Stenotrophomonas [11, 27]. This is not surprising, as one likely origin of the raw milk microbiota is the microflora of the teat skin that contaminates the milk during milking.

Apart from contamination at collection, the finding of bacterial DNA in milk samples could result from the presence of dead bacteria or bacterial fragments. This bacterial DNA could be either free in milk, or translocated into the MG lumen by migrating leucocytes, as discussed above. Importantly, beyond the sample contamination controversy, it is necessary to take into account all the consequences and implications related to the existence of an intramammary microbiota, in terms of pathogenesis of infectious mastitis, immunobiology of the MG, and dairy cow husbandry, including good hygienic practices.

\section{Mammary microbiota and the innate immunity of the MG}

The immune response that develops in reaction to pathogens is shaped by the host-bacteria interactions that prevail in the infected organ [28]. The existence of a microbiota is an important determinant of the organspecific regulation of innate immunity. Knowing whether the MG is devoid of a resident microbiota, or whether the healthy MG accommodates harmless bacterial inhabitants is thus of high significance and consequence.

\subsection{Milk is a nutrient-rich medium that supports the growth of bacteria}

Milk is a medium permissive to the growth of many bacterial species. The most prevalent mastitis-associated bacteria are able to multiply in vivo with a doubling time of 20-30 min during the first few hours following entry into the MG [29]. Another indication that milk has a limited antibacterial efficiency is that it is easy to induce intramammary infections by introducing small numbers of microorganisms through the teat canal. It has been shown that if even very few (1-10 cfu) streptococci [30], staphylococci [31] or Escherichia coli [32] gain access to the teat cistern of uninflamed glands, bacterial multiplication takes place and infection ensues. When the defenses of the MG are compromised, it is common for the infecting bacteria to reach concentrations above $10^{6}$ or $10^{8} \mathrm{cfu} / \mathrm{mL}$ in milk $[25,29]$. Although review articles listing the defenses of the bovine mammary gland generally conclude that milk is well equipped with antibacterial substances [33-35], it is of common knowledge that freshly drawn milk spoils in a few hours if not refrigerated. Cheese making has been developed by dairymen to overcome this propensity of milk to let unwanted microorganisms proliferate. The addition of beneficial microbiota is used to overwhelm the undesirable bacteria. The mere fact that it is possible to grow a "positive" microflora in freshly drawn milk demonstrates that milk has a limited inhibitory potential. Also, raw milk aseptically drawn from healthy glands has been used in vitro as a growth medium to test the activity of antimicrobials against mastitis-causing bacteria, without detectable interference by a putative indigenous microbiota [36].

One implication of the above considerations is that once they are within the lumen of a lactating MG, many bacterial species are able to proliferate and reach high concentrations, unless a prompt immune reaction hampers their growth. This puts a very high pressure on the gate-keeper function of the teat canal. As way of compensation to this vulnerability, the MG has the capacity to detect microorganisms. This is the task of the innate immune system. 


\subsection{The mammary gland is poised to sense and to react to MAMPs}

In a sterile organ, the triggering of receptors of the innate immune system (the Pattern Recognition Receptors, PRR) by the Microbe-Associated Molecular Patterns (MAMPs) activates inflammatory cascades that generate a quick antibacterial reaction, but this does not apply to organs such as the gut or the skin, which are laden with commensals or symbionts and constantly confronted with MAMPs [28]. Normally, the constant stimulation of the colonized epithelium induces a tolerance to the local microbiota. For example, the gut is tolerant to bacterial lipopolysaccharide (LPS) so it does not react to relatively high amounts of this MAMP. This is not the case with the bovine mammary gland, which responds to low amounts of LPS by an influx of leucocytes into milk [37]. In fact, the MG is well equipped to detect bacteria and the components they release: infusion of MAMPs into the MG through the teat canal elicits strong inflammatory responses [3840]. Mammary epithelial cells express Toll-like receptors (TLRs) at their apical face, and are equipped to detect bacterial intrusion and to trigger an inflammatory response $[41,42]$. This reactivity is at variance with the existence of an intramammary microbiota, as epithelial cells exposed to bacterial communities are usually poorly responsive to MAMPs, possibly to avoid excess reactivity to the microbiota. This is because "TLRs bear little ability to distinguish between commensal and pathogenic microbes as such organisms generally bear far more structural similarities than differences between them" [43].

\subsection{There is no mucus shield to protect the mammary epithelium from a microbiota}

The mammary gland is not a mucosal organ, and in particular its epithelium does not secrete a mucus [44]. Mucus secreted by specialized cells of the mucosal epithelia plays an important role in the epithelium/microbiota interactions, by limiting direct contact of the bacteria with the epithelium lining [45]. In mouse models, defects in the mucus layer, such as genetic ablation of the major mucin MUC2, allow increased contact of commensal bacteria with intestinal epithelial cells and lead to spontaneous colitis [46]. This observation suggests that, as there is no mucus layer to keep commensal bacteria at a distance from the mammary epithelium, an intramammary microbiota would induce mastitis. Another role of mucus is to concentrate antibodies of the secretory immunoglobulin A ( $\operatorname{sg} \mathrm{A})$ type and antimicrobial peptides in the mucus shield [45]. The very low concentration of sIgA $(0.1-0.2 \mathrm{mg} / \mathrm{mL})$ in milk of dairy ruminants is at variance with the existence of an intramammary microbiota, because microbiota generally stimulate multiple pathways to drive secretory IgA production by plasma cells located in the lamina propria $[44,47,48]$. This low sIgA

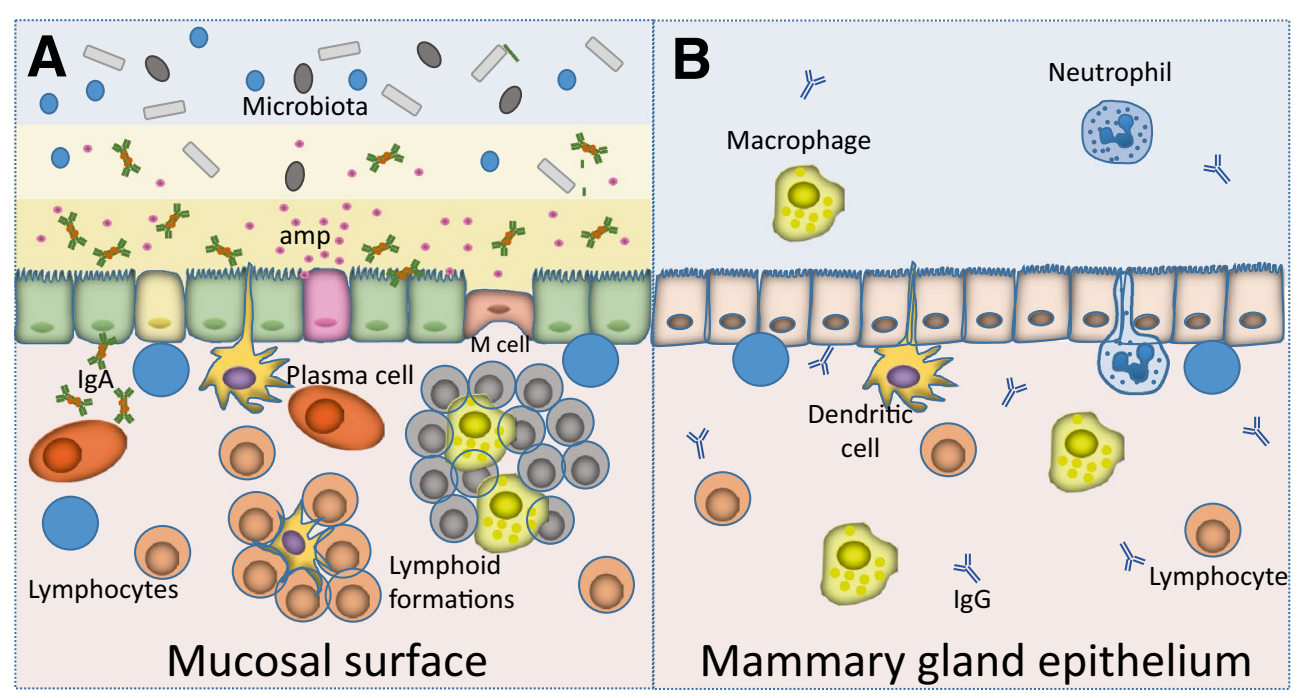

Figure 1 The mammary gland epithelium is not a mucosal epithelium. A Mucosal surfaces colonized by bacterial communities deploy distinct protective mechanisms. Within the simple columnar epithelium, goblet cells secrete mucus that covers the mucosal surface. The mucus inner and outer layers retain high concentrations of secretory lgA and host antimicrobial peptides (amp) secreted by epithelial cells or specialized cells such as Paneth cells. M cells transport luminal antigens to the dendritic cells beneath. Plasma cells secrete slgA. T and B cells are present in the lamina propria, some are associated in mucosa-associated lymphoid formations. B The mammary gland epithelium is devoid of mucus, and bovine milk contains low-concentration of IgG. A few macrophages and neutrophils can be found in the lumen, but neutrophils are recruited en masse by inflammation when bacteria proliferate in milk. Bacterial intruders are detected by the epithelium comprised of epithelial cells and intraepithelial dendritic cells. Macrophages and T cells are present in the lamina propria, but organised lymphoid formations are absent from healthy glands. 
concentration and the paucity of IgA-producing B lymphocytes in the healthy MG do not stem from an inherent incompetence of the MG, because it is possible to induce the production of IgA in the MG of ruminants by intramammary antigenic stimulation [49]. This strongly suggests that there is no permanent antigenic stimulation inside the mammary gland.

\subsection{Absence or rarity of isolated lymphoid follicles}

Isolated lymphoid follicles (ILF) and associated $\mathrm{T}$ cell clusters (only visible microscopically) are common throughout the intestinal tract and occur in many mucosal locations. They are induced by exposure to antigens and microorganisms. ILFs in the upper respiratory tract are generally present only under conditions of antigenic challenge [50]. ILFs are also common at mucocutaneous transitions and near the ducts of secretory glands that empty onto mucosal surfaces [51]. ILFs have seldom been described in the bovine MG, mainly in the folds of the distal rosette of the teat cistern (Furstenberg's rosette) [52]. ILFs were not detected in mammary tissue of MG that did not shed "conventional" mastitis-causing bacteria [53]. The rarity of ILFs in the MG constitutes another argument against the existence of an intramammary microbiota. Overall, there are major dissimilarities between a typical mucosal epithelium and the intramammary epithelium of dairy ruminants (Figure 1).

\subsection{Inefficiency of the entero-mammary pathway in ruminants}

The entero-mammary pathway hypothesis states that some immune cells primed in the gut lamina propria can migrate to the mammary gland. This pathway has been shown to operate in rodents for lymphocytes and is also believed to operate in humans [19]. The entero-mammary pathway has been invoked to explain the transfer of gut lumen bacteria to the mammary gland [15]. Nevertheless, in cattle and sheep, a gut origin for MG lymphocytes is unlikely as mesenteric lymph node cells do not migrate to the MG [54]. It is unlikely that the gutmammary pathway operates in dairy ruminants, because the MG of ruminants is not part of the common mucosal immune system as originally defined in monogastric species $[44,55]$. Although the endogenous route may explain MG infection and the excretion of intracellular pathogens such as Mycobacterium tuberculosis or Brucella in the milk or milk cells of systemically infected animals, it is widely held that the teat canal forms the main portal of entry of microorganisms to the udder $[8$, 56]. It is noteworthy that bearing in mind the very low bacterial numbers necessary to induce intramammary infections, the continued ingress of viable bacteria-laden macrophages or dendritic cells from the gut or other sites into the MG lumen would pose a formidable threat to the MG.

Another origin of bacterial DNA in milk could be the passage of dead bacteria or circulating bacterial components from blood to milk. It is known that bacterial components can be found transiently in blood and that translocation of bacterial peptidoglycan to the bone marrow occurs $[57,58]$. As the MG is richly vascularized and filters huge amounts of blood during lactation, it can be envisaged that some of these circulating bacterial components find their way into the milk. Yet, two considerations contradict this view. First, the mammary epithelium border is almost impermeable, preventing the crossing of even small molecules both ways (i.e. albumin from blood to milk, and lactose from milk to blood), although food proteins can be found in breast milk [59]. Second, the MG epithelium is very sensitive to MAMPs such as endotoxins, lipoproteins, peptidoglycan fragments, bacterial DNA or RNA. One possibility then is that the bacterial components, and among them 16S RNA, are shuttled in milk within phagocytic cells. These cells, monocytes or neutrophils, patrolling the mammary tissue, would occasionally traverse the epithelium and be shed in milk. Whole bacteria could even be carried by phagocytes, as long as live bacteria were not released in milk, in which case mastitis would ensue. Interestingly, according to the hypothesis of bacterial DNA as a cargo of migrating leucocytes, in the case of mastitis many blood leucocytes are recruited into milk, thus increasing the probability of recovering bacterial DNA in milk. This is in keeping with results showing the absence of bacterial DNA in the milk of non-infectious mastitis and the presence of DNA of many bacterial types in the milk of breast-infected women [60].

In conclusion, the existence of an intramammary microbiota seems incompatible with the established knowledge of the innate and adaptive immune system of the MG.

\section{Mammary microbiota compatibility with the five-point mastitis control plan}

The question arises of the compatibility of the concept of intramammary microbiota with the mastitis control practices developed and endorsed by researchers at the National Institute for Research in Dairying (NIRD, UK) in the 1960s [61]. Specifically, is the mammary microbiota compatible with systematic dry cow therapy and teat dipping in disinfectant solutions? The routine use of disinfectant teat dipping after milking has been established as the best technique to reduce substantially new infections rates at the herd level [62]. Large field experiments indicated that the main direct effects of teat dipping were to reduce general skin contamination and 
prevent teat orifice infections $[62,63]$. The main purpose of a teat dip is to destroy contaminating pathogens at the teat apex and the external opening of the canal, thus preventing infection of the teat canal. It ensures that any microbial community of the teat apex is compromised by the routine disinfectant teat dipping. Yet, this impact on the teat microbial colonisation results in a proven reduction in new intramammary infection rates [64]. Thus the widely accepted efficacy of post-milking teat dipping discredits the potential efficiently protective effect of a teat microbiota. Systematic or blanket drying-off therapy, i.e. intramammary treatment of all udder quarters with longacting antibiotics at the beginning of the dry period, has been recommended for a long time because it proved to reduce efficiently the level of infection at the herd level $[62,65]$. The products used are mainly effective against Gram positive bacteria, yet there is no increase in the prevalence of infections by Gram negative bacteria associated to their use $[63,65,66]$. Blanket drying-off therapy with long-acting (more than three weeks) antibiotic concentrations has the potential to interfere durably with any putative intramammary microbiota, and microbiota disruption by antibacterial products is known to favour dysbiosis, which may increase the susceptibility to infections after the cessation of treatment [67]. The proven efficacy of blanket dry cow therapy in reducing the incidence of new intramammary infections is another circumstantial evidence of the inefficiency of the putative intramammary microbiota, and is compatible with the idea that such a microbiota does not exist.

\section{An implication of mammary microbiota: use of probiotics for the mammary gland}

According to the concept of mastitis as a manifestation of dysbiosis, i.e. an imbalance of the intramammary microbiota, the use of probiotics to re-equilibrate the microbiota appears as a possible corrective measure. Oral probiotics for the treatment of breast infections have been evaluated [68]. The oral route of administration is not likely to operate effectively in polygastric animals such as ruminants, especially since the enteromammary pathway is poorly operative in these species. This is probably why probiotics for the bovine MG have been administered through the teat canal. Several Lactobacillus species or strains of Lactococcus lactis have been used as intramammary probiotics. The probiotic L. lactis DPC 3147 has been used as an alternative non-antibiotic treatment of mastitis, and its injection into the MG induces a sizeable inflammatory response [69]. In fact, L. lactis, although a Generally Regarded As Safe bacterium (GRAS), is a mastitis-causing pathogen [70, 71]. Intramammary inoculation of a commercial probiotic mixture of Lactobacillus acidophilus and
Lactobacillus casei to cure mastitis has been found not to be efficient and caused a local inflammatory response [72]. Intramammary infusion of $10^{6} \mathrm{cfu}$ of Lactobacillus perolens induced a mild inflammatory response, but its capacity to treat or prevent intramammary infections has not been demonstrated [73]. It appears that probiotic bacteria trigger an inflammatory response from the MG, and this is probably why they have been used for therapy rather than for prevention of intramammary infections (IMI). Concerning the prevention of new infections by pre-existing and long-lasting colonization of the MG by bacteria, an experiment of nature in relation to intramammary probiotics is the effect of the so-called minor pathogens Corynebacterium bovis and coagulase-negative staphylococci on the incidence of IMI by major pathogens such as S. aureus, streptococci and $E$. coli. Although quite a few studies reported some protective effect by minor pathogens, others have found the converse or no effect, and several ancient and recent reviews conclude that a protective effect would be of low magnitude in any case [74-77]. It is noteworthy that the efficiency of the alleged intramammary microbiota would be low, since a few (1-100) S. aureus or E. coli cfu are enough to cause mastitis with a success rate above $90 \%$ $[32,78,79]$.

Probiotics are supposed to act by competitive exclusion. Certain milk bacterial strains have the capacity of inhibiting the growth of mastitis-causing bacteria in vitro, possibly through the production of bacteriocins, but this effect requires high concentrations of the interfering bacteria [80]. Yet the normal mammary microbiota is reported to comprise less than 3-4.7 $\log _{10} \mathrm{CFU} / \mathrm{mL}$ $[6,20]$. The low concentration of milk bacteria in healthy glands and the frequent renewal of milk make the effective production of bacteriocins unlikely. Competitive exclusion has never been shown in milk in conditions mimicking the in vivo situation.

Two different logics conflict on the reactivity of the MG to bacteria. If we posit that an intramammary microbiota is a feature of the normal MG, then there must be a state of tolerance of the microorganisms composing the microbiota by the intramammary epithelium lining. Therefore, it could be possible to harness this microbiota or the tolerance to some microorganisms to enhance the resistance or resilience of the MG to mastitis-causing pathogens through the use of well-chosen probiotics. Although regulatory $\mathrm{T}$ cells have been found in the mouse mammary gland [81], published results to date do not support this possibility. Alternatively, if we posit that the normal MG is a sterile organ, then we can expect that any microorganism penetrating the lumen of the gland would trigger a response from the MG as soon as the threshold of reactivity was reached, because a sterile organ is not poised to 
tolerate a microbiota. Convergent data support this alternative view, casting doubt on the potential of probiotics as a potential preventive solution for mastitis control.

\section{The concept of mammary microbiota needs thorough examination}

There is accumulating evidence that complex communities of microbes play a fundamental role in controlling many aspects of host physiology. A spate of studies reflects the excitement that pervades the scientific community, giving rise to the emergence of "microbiomics" accompanying the microbiota upheaval. To avoid being carried away by this hype, it is appropriate to apply a healthy dose of scepticism to microbiome science [82]. The novel concept of mammary microbiota has not previously been examined with regard to its implications in terms of mammary immunobiology. The proponents of the intramammary microbiota theory have not discussed the implications of their studies in relation with the current mastitis control practices and the ancient and most recent developments in mammary gland immunobiology. It appears that the intramammary microbiota concept is inconsistent with the properties of milk as a growth medium, the reactivity of the bovine MG to MAMPs, the absence of mucosal firewall to bacteria, and the paucity of organized lymphoid tissue in the lamina propria. Overall, the existence of an intramammary microbiota seems incompatible with the known data concerning the status of the innate and adaptive immune system of the MG. In addition, the mammary microbiota does not dovetail with data from experimentally induced mastitis and the success of the mastitis control measures currently in use. These discrepancies between the concept of mammary microbiota and the established knowledge of mammary infection immunobiology cast doubt on the efficacy and practicality of the intramammary probiotics approach to controlling mastitis. Although the existence and importance of a teat apex microbiota deserves attention, it is the opinion of the author that the existence of an intramammary microbiota is a fiction that could cause confusion and interfere with practices that have proved useful for mastitis control.

\section{Competing interests}

The author declares that he has no competing interests.

\section{Acknowledgements}

The author thanks Bernard Poutrel and Gilles Foucras for their useful comments and helpful discussions.

\section{Publisher's Note}

Springer Nature remains neutral with regard to jurisdictional claims in published maps and institutional affiliations.

Received: 14 February 2017 Accepted: 21 March 2017

Published online: 17 April 2017
References

1. Costello EK, Lauber CL, Hamady M, Fierer N, Gordon Jl, Knight R (2009) Bacterial community variation in human body habitats across space and time. Science 326:1694-1697

2. Belkaid Y, Hand TW (2014) Role of the microbiota in immunity and inflammation. Cell 157:121-141

3. Dickson RP, Huffnagle GB (2015) The lung microbiome: new principles for respiratory bacteriology in health and disease. PLoS Pathog 11:e1004923

4. Oikonomou G, Machado VS, Santisteban C, Schukken YH, Bicalho RC (2012) Microbial diversity of bovine mastitic milk as described by pyrosequencing of metagenomic 16s rDNA. PLoS One 7:e47671

5. Martín R, Heilig HG, Zoetendal EG, Jiménez E, Fernández L, Smidt H, Rodríguez JM (2007) Cultivation-independent assessment of the bacterial diversity of breast milk among healthy women. Res Microbiol 158:31-37

6. Falentin H, Rault L, Nicolas A, Bouchard DS, Lassalas J, Lamberton P, Aubry JM, Marnet PG, Le Loir Y, Even S (2016) Bovine teat microbiome analysis revealed reduced alpha diversity and significant changes in taxonomic profiles in quarters with a history of mastitis. Front Microbiol 7:480

7. Lister J (1878) Little and Plastridge. Bovine mastitis, $1^{\text {st }}$ ed. McGraw-Hill Book Co., New York, p 190

8. Plastridge WN (1958) Bovine mastitis: a review. J Dairy Sci 41:1141-1181

9. Neave FK (1975) Diagnosis of mastitis by bacteriological methods alone. In: Dodd FH, Griffin TK, Kingwill RG (eds) IDF seminar on mastitis control, Reading, UK, pp 19-36

10. Zadoks RN, Fitzpatrick JL (2009) Changing trends in mastitis. Ir Vet J 62:59-70

11. Kuehn JS, Gorden PJ, Munro D, Rong R, Dong Q, Plummer PJ, Wang C, Phillips GJ (2013) Bacterial community profiling of milk samples as a means to understand culture-negative bovine clinical mastitis. PLoS One 8:e61959

12. Oikonomou G, Bicalho ML, Meira E, Rossi RE, Foditsch C, Machado VS, Teixeira AG, Santisteban C, Schukken YH, Bicalho RC (2014) Microbiota of cow's milk; distinguishing healthy, sub-clinically and clinically diseased quarters. PLoS One 9:e85904

13. Jeurink PV, van Bergenhenegouwen J, Jimenez E, Knippels LM, Fernandez L, Garssen J, Knol J, Rodriguez JM, Martin R (2013) Human milk: a source of more life than we imagine. Benef Microbes 4:17-30

14. World Health Organisation (WHO) (2000) Mastitis: causes and management. In: development DoCaAha (ed), Geneva, Switzerland

15. Perez PF, Doré J, Leclerc M, Levenez F, Benyacoub J, Serrant P, SeguraRoggero I, Schiffrin EJ, Donnet-Hughes A (2007) Bacterial imprinting of the neonatal immune system: lessons from maternal cells? Pediatrics 119:e724-e732

16. Duncan JT, Walker J (1942) Staphylococcus aureus in the milk of nursing mothers and the alimentary canal of their infants: a report to the Medical Research Council. J Hyg 42:474-484

17. Hunt KM, Foster JA, Forney LJ, Schutte UM, Beck DL, Abdo Z, Fox LK, Williams JE, McGuire MK, McGuire MA (2011) Characterization of the diversity and temporal stability of bacterial communities in human milk. PLoS One 6:e21313

18. Martín $R$, Langa $S$, Reviriego $C$, Jiménez E, Olivares M, Boza J, Jiménez J, Fernández L, Xaus J, Rodríguez M (2004) The commensal microflora of human milk: new perpectives for food bacteriotherapy and probiotics. Trends Food Sci Technol 15:121-127

19. Parmely MJ, Beer AE (1977) Colostral cell-mediated immunity and the concept of a common secretory immune system. J Dairy Sci 60:655-665

20. Contreras GA, Rodríguez JM (2011) Mastitis: comparative etiology and epidemiology. J Mammary Gland Biol Neoplasia 16:339-356

21. Watts JL (1988) Etiological agents of bovine mastitis. Vet Microbiol 16:41-66

22. Watts JL, Yancey RJ Jr (1994) Identification of veterinary pathogens by use of commercial identification systems and new trends in antimicrobial susceptibility testing of veterinary pathogens. Clin Microbiol Rev 7:346-356

23. Braem G, De Vliegher S, Verbist B, Heyndrickx M, Leroy F, De Vuyst L (2012) Culture-independent exploration of the teat apex microbiota of dairy cows reveals a wide bacterial species diversity. Vet Microbiol 157:383-390

24. Vangroenweghe F, Dosogne H, Mehrzad J, Burvenich C (2001) Effect of milk sampling techniques on milk composition, bacterial contamination, viability and functions of resident cells in milk. Vet Res 32:565-579 
25. Pyörälä S, Jousimies-Somer H, Mero M (1992) Clinical, bacteriological and therapeutic aspects of bovine mastitis caused by aerobic and anaerobic pathogens. Br Vet J 148:54-62

26. Pyörälä S (2012) Letter to the editor: comments on Schwaiger et al. (2012). J Dairy Sci 95:4185

27. Vacheyrou M, Normand AC, Guyot P, Cassagne C, Piarroux R, Bouton Y (2011) Cultivable microbial communities in raw cow milk and potential transfers from stables of 16 French farms. Int J Food Microbiol 146:253-262

28. Raz E (2007) Organ-specific regulation of innate immunity. Nat Immunol 8:3-4

29. Rainard P, Riollet C (2003) Mobilization of neutrophils and defense of the bovine mammary gland. Reprod Nutr Dev 43:439-457

30. Murphy JM, Stuart OM (1953) The effect of introducing small numbers of Streptococcus agalactiae (Cornell 48 strain) directly into the bovine teat cavity. Cornell Vet 43:290-310

31. Newbould FHS, Neave FK (1965) The recovery of small numbers of Staphylococcus aureus infused into the bovine teat cistern. J Dairy Res 32:157-162

32. Hill AW, Shears AL, Hibbitt KG (1978) The elimination of serum-resistant Escherichia coli from experimentally infected single mammary glands of healthy cows. Res Vet Sci 25:89-93

33. Wheeler TT, Smolenski GA, Harris DP, Gupta SK, Haigh BJ, Broadhurst MK Molenaar AJ, Stelwagen K (2012) Host-defence-related proteins in cows' milk. Animal 6:415-422

34. Kolb AF (2002) Engineering immunity in the mammary gland. J Mammary Gland Biol Neoplasia 7:123-134

35. Goldman AS (2002) Evolution of the mammary gland defense system and the ontogeny of the immune system. J Mammary Gland Biol Neoplasia 7:277-289

36. Fang W, Pyörälä S (1996) Mastitis-causing Escherichia coli: serum sensitivity and susceptibility to selected antibacterials in milk. J Dairy Sci 79:76-82

37. Shuster DE, Kehrli ME Jr, Stevens MG (1993) Cytokine production during endotoxin-induced mastitis in lactating dairy cows. Am J Vet Res 54:80-85

38. Porcherie A, Cunha P, Trotereau A, Roussel P, Gilbert FB, Rainard P, Germon P (2012) Repertoire of Escherichia coli agonists sensed by innate immunity receptors of the bovine udder and mammary epithelial cells. Vet Res 43:14

39. Bougarn S, Cunha P, Harmache A, Fromageau A, Gilbert BF, Rainard P (2010) Muramyl dipeptide synergizes with Staphylococcus aureus lipoteichoic acid to recruit neutrophils in the mammary gland and to stimulate mammary epithelial cells. Clin Vaccine Immunol 17:1797-1809

40. Gilbert FB, Cunha P, Jensen K, Glass EJ, Foucras G, Robert-Granié C, Rupp R, Rainard P (2013) Differential response of bovine mammary epithelial cells to Staphylococcus aureus or Escherichia coli agonists of the innate immune system. Vet Res 44:40

41. PetzI W, Zerbe H, Gunther J, Yang W, Seyfert HM, Nurnberg G, Schuberth HJ (2008) Escherichia coli, but not Staphylococcus aureus triggers an early increased expression of factors contributing to the innate immune defense in the udder of the cow. Vet Res 39:18

42. Rainard P, Riollet C (2006) Innate immunity of the bovine mammary gland. Vet Res 37:369-400

43. Gewirtz AT (2003) Intestinal epithelial toll-like receptors: to protect. And serve? Curr Pharm Des 9:1-5

44. Butler JE, Rainard P, Lippolis JD, Salmon H, Kacskovics I (2015) The mammary gland in mucosal and regional immunity. In: Mestecky J, Strober W, Russell M, Cheroutre H, Lambrecht BN, Kelsall BL (eds) Mucosal immunology. Academic Press, Cambridge, pp 2269-2306

45. Gutzeit C, Magri G, Cerutti A (2014) Intestinal IgA production and its role in host-microbe interaction. Immunol Rev 260:76-85

46. Van der Sluis M, De Koning BA, De Bruijn AC, Velcich A, Meijerink JP, Van Goudoever JB, Buller HA, Dekker J, Van Seuningen I, Renes IB, Einerhand AW (2006) Muc2-deficient mice spontaneously develop colitis, indicating that MUC2 is critical for colonic protection. Gastroenterology 131:117-129

47. Kabat AM, Srinivasan N, Maloy KJ (2014) Modulation of immune development and function by intestinal microbiota. Trends Immunol 35:507-517

48. Butler JE (1981) A concept of humoral immunity among ruminants and an approach to its investigation. Adv Exp Med Biol 137:3-55
49. Lascelles AK, McDowell GH (1970) Secretion of IgA in the sheep following local antigenic stimulation. Immunology 19:613-620

50. Bienenstock J, Clancy RL (2005) Bronchus-associated lymphoid tissues. In: Mestecky J, Bienenstock J, Lamm M, Mayer L, McGhee JR, Strober W (eds) Mucosal immunology, 3rd edn. Academic Press, San Diego, pp 375-384

51. Neutra MR, Kraehenbuhl JP (2011) Immune defense at mucosal surfaces. In: Kaufmann SHE, Rouse BT, Sacks DL (eds) The immune response to infection. ASM Press, Washington, DC, pp 97-107

52. Collins RA, Parsons KR, Bland AP (1986) Antibody-containing cells and specialised epithelial cells in the bovine teat. Res Vet Sci 41:50-55

53. Akers RM, Nickerson SC (2011) Mastitis and its impact on structure and function in the ruminant mammary gland. J Mammary Gland Biol Neoplasia 16:275-289

54. Harp JA, Runnels PL, Pesch BA (1988) Lymphocyte recirculation in cattle: patterns of localization by mammary and mesenteric lymph node lymphocytes. Vet Immunol Immunopathol 20:31-39

55. Kehrli ME Jr, Harp JA (2001) Immunity in the mammary gland. Vet Clin North Am Food Anim Pract 17:495-516

56. Newbould FHS (1964) Factors affecting bacterial invasion of the bovine udder via the teat duct. Dairy Sci Abstr 26:245-255

57. Belkaid Y, Naik S (2013) Compartmentalized and systemic control of tissue immunity by commensals. Nat Immunol 14:646-653

58. Clarke TB, Davis KM, Lysenko ES, Zhou AY, Yu Y, Weiser JN (2010) Recognition of peptidoglycan from the microbiota by Nod1 enhances systemic innate immunity. Nat Med 16:228-231

59. Julia V, Macia L, Dombrowicz D (2015) The impact of diet on asthma and allergic diseases. Nat Rev Immunol 15:308-322

60. Delgado S, Collado MC, Fernández L, Rodríguez JM (2009) Bacterial analysis of breast milk: a tool to differentiate Raynaud's phenomenon from infectious mastitis during lactation. Curr Microbiol 59:59-64

61. Dodd FH, Westgarth DR, Neave FK, Kingwill RG (1969) Mastitis — the strategy of control. J Dairy Sci 52:689-695

62. Neave FK, Dodd FH, Kingwill RG, Westgarth DR (1969) Control of mastitis in the dairy herd by hygiene and management. J Dairy Sci 52:696-707

63. Dodd FH, Neave FK (1970) Mastitis control. Rep Natl Inst Res Dairy Bienn Rev 1970:21-60

64. Philpot WN, Pankey JW, Boddie RL (1978) Hygiene in the prevention of udder infections. VI. Comparative efficacy of a teat dip under experimental and natural exposure to mastitis pathogens. J Dairy Sci 61:964-969

65. Robert A, Seegers H, Bareille N (2006) Incidence of intramammary infections during the dry period without or with antibiotic treatment in dairy cows-a quantitative analysis of published data. Vet Res 37:25-48

66. Philpot WN (1979) Control of mastitis by hygiene and therapy. J Dairy Sci 62:168-176

67. Keeney KM, Yurist-Doutsch S, Arrieta MC, Finlay BB (2014) Effects of antibiotics on human microbiota and subsequent disease. Annu Rev Microbiol 68:217-235

68. Jiménez E, Fernández L, Maldonado A, Martín R, Olivares M, Xaus J, Rodríguez JM (2008) Oral administration of Lactobacillus strains isolated from breast milk as an alternative for the treatment of infectious mastitis during lactation. Appl Environ Microbiol 74:4650-4655

69. Beecher C, Daly M, Berry DP, Klostermann K, Flynn J, Meaney W, Hill C, McCarthy TV, Ross RP, Giblin L (2009) Administration of a live culture of Lactococcus lactis DPC 3147 into the bovine mammary gland stimulates the local host immune response, particularly IL-1beta and IL-8 gene expression. J Dairy Res 76:340-348

70. Plumed-Ferrer C, Uusikylä K, Korhonen J, von Wright A (2013) Characterization of Lactococcus lactis isolates from bovine mastitis. Vet Microbiol 167:592-599

71. Werner B, Moroni P, Gioia G, Lavin-Alconero L, Yousaf A, Charter ME, Carter BM, Bennett J, Nydam DV, Welcome F, Schukken YH (2014) Short communication: genotypic and phenotypic identification of environmental streptococci and association of Lactococcus lactis ssp. lactis with intramammary infections among different dairy farms. J Dairy Sci 97:6964-6969

72. Greene WA, Gano AM, Smith KL, Hogan JS, Todhunter DA (1991) Comparison of probiotic and antibiotic intramammary therapy of cattle with elevated somatic cell counts. J Dairy Sci 74:2976-2981

73. Frola ID, Pellegrino MS, Magnano G, Giraudo JA, Espeche MC, NaderMacias ME, Bogni Cl (2013) Histological examination of non-lactating 
bovine udders inoculated with Lactobacillus perolens CRL 1724. J Dairy Res 80:28-35

74. Pyorälä S, Taponen S (2009) Coagulase-negative staphylococci-emerging mastitis pathogens. Vet Microbiol 134:3-8

75. Reyher KK, Haine D, Dohoo IR, Revie CW (2012) Examining the effect of intramammary infections with minor mastitis pathogens on the acquisition of new intramammary infections with major mastitis pathogens-a systematic review and meta-analysis. J Dairy Sci 95:6483-6502

76. Rainard P (1987) Should mammary infections caused by Corynebacterium bovis and coagulase-negative staphylococci be eliminated? Ann Vet Res 18:355-364 (in French)

77. Poutrel B, Lerondelle C (1980) Protective effect in the lactating bovine mammary gland induced by coagulase negative staphylococci against experimental Staphylococcus aureus infections. Ann Rech Vet 11:327-332

78. Newbould FHS, Neave FK (1965) The response of the bovine mammary gland to an infusion of staphylococci. J Dairy Res 32:163-170
79. Poutrel B, Lerondelle C (1978) Induced staphylococcal infections in the bovine mammary gland. Influence of the month of lactation and other factors related to the cow. Ann Rech Vet 9:119-128

80. Aguilar C, Vanegas C, Klotz B (2010) Antagonistic effect of Lactobacillus strains against Escherichia coli and Listeria monocytogenes in milk. J Dairy Res 78:136-143

81. Porcherie A, Gilbert FB, Germon P, Cunha P, Trotereau A, Rossignol C, Winter N, Berthon P, Rainard P (2016) IL-17A is an important effector of the immune response of the mammary gland to Escherichia coli infection. J Immunol 196:803-812

82. Hanage WP (2014) Microbiology: microbiome science needs a healthy dose of scepticism. Nature 512:247-248

\section{Submit your next manuscript to BioMed Central and we will help you at every step:}

- We accept pre-submission inquiries

- Our selector tool helps you to find the most relevant journal

- We provide round the clock customer support

- Convenient online submission

- Thorough peer review

- Inclusion in PubMed and all major indexing services

- Maximum visibility for your research

Submit your manuscript at www.biomedcentral com/submit 